\title{
Embryonic Modernity: Infectious Dynamics in Early Nineteenth-Century Finnish Culture
}

\author{
Hannu Salmi \\ Academy Professor; Cultural History, School of History, Culture and \\ Arts Studies, University of Turku, Turku, Finland \\ hansalmi@utu.fi \\ Jukka Sarjala \\ Title of Docent; Cultural History, School of History, Culture and Arts Studies, \\ University of Turku, Turku, Finland \\ juksar@utu.fi

\section{Heli Rantala} \\ Postdoctoral researcher; Cultural History, School of History, Culture and \\ Arts Studies, University of Turku, Turku, Finland \\ hemara@utu.fi
}

\begin{abstract}
The article explores the early decades of the nineteenth century as an era of what we call embryonic modernity. It focuses on Finland which, in 1809, became a Grand Duchy of the Russian empire. The article concentrates on early mass phenomena as embryos of an emerging modern culture. We scrutinize our subject through three different lenses, starting with social infectivity on a minor scale, the unrest caused by students. We then investigate the contagiousness of ideas seen through the press as a news medium in the 1820 . The last section concentrates on the news about cholera and its rapid spread during the early $1830 \mathrm{os}$. We argue that historical embryos were formations of social relationality, composed of affects, beliefs, expectations and sentiments. These formations of emotive dynamics had the capacity to be imitated; they became components of larger social entities by extending their contagiousness to new regions and populations.
\end{abstract}




\section{Keywords}

history of emotions - virality - social and material infectivity - entangled history modernity

\section{Introduction}

This article concentrates on social and political transformation in the early nineteenth century with a focus on Finland. At the turn of the century, Finland was a sparsely populated area with pre-modern infrastructure within the Swedish kingdom. Although administratively a fully integrated part of Sweden, the Finnish side of the realm had distinctive features, such as its language. The majority of the population in Finland consisted of Finnish-speaking peasantry. The degree of urbanization was very low, although the largest town, Turku (Åbo in Swedish), a mid-sized town by European standards, was actually one of the largest in the whole kingdom. ${ }^{1}$

Despite its remote location, Finland by no means remained unaffected by the political unrest sweeping across the European continent, most notably the French Revolution and the years of Napoleonic rule. After the 1808-1809 war between Sweden and Russia, the Finnish area was separated from Sweden, and the Grand Duchy of Finland was established within the autocratically-ruled Russian empire. In many ways, Finland became a meeting ground for the reactionary interests of the Russian empire and the broader European political turmoil.

The aim of this article is to explore the early decades of the nineteenth century as an era of what we call 'embryonic modernity'. The concept is our suggestion, and it entails the idea that the first decades of the Grand Duchy initiated processes that later became central in the construction of Finland as a cultural, social and political whole. The article concentrates on early mass phenomena that we see as embryos of an emerging modern culture. We will elaborate this basic idea throughout the article and return to the notion of embryonic modernity in the conclusion. Our agenda has been motivated by Jürgen Osterhammel and his remarkable overview of the nineteenth century, The Transformation of the World, in which he considers the problem of modernity. Is the birth of modernity, which by definition could happen only once at a particular time and place, the only aspect we should address? 'Is it enough', Osterhammel ponders, 'that modern principles came into the world

1 Savolainen 2017,45 . 
somewhere and sometime', or should we be more concerned with how they 'spread and took effect'?

Inspired by this question, we will examine the processes of transmission by which modern phenomena such as academic activism, revolutionary turmoil and the spread of news took shape in early nineteenth-century Finland. However, these historical 'embryos', as we see them, did not have any teleological drive, as if the development of Finnish society was bound to follow a hidden code embedded in them. Rather, we regard historical embryos as formations of social relationality composed of affects, beliefs, expectations and sentiments. These formations of emotive dynamics have the capacity to be imitated; they can become components of larger social entities by extending their 'contagiousness' to new regions and populations. ${ }^{3}$ We will deal with the question of how this kind of infectious dynamics created a stronger interdependence between people and the environments in which they lived in early nineteenth-century Finland. We hope that the following yields a different picture of this period in Finnish history, which usually evokes an image of vast regions consisting of sparsely populated woodlands.

\section{$2 \quad$ Virality and Modernity}

Moreover, we hope that this article will give incentives for studying infectiousness and its potential more carefully in the development of modernity in general. Our analysis has been fuelled by recent debates and theorizing on virality, as discussed by Tony D. Sampson in his Virality: Contagion Theory in the Age of Networks (2012). ${ }^{4}$ In the current age of the internet and social media, it is common to talk about something 'going viral. 5 This phenomenon is widespread; it extends on a global scale with tens of millions of people sharing and remixing

2 Osterhammel 2014, 905.

3 On French sociologist Gabriel Tarde's ideas on epidemiological microrelations and their social relevance to contemporary contagion theory, see Sampson 2012, 17-19, 40. Infectiousness has also been studied in meme theory by scholars such as Susan Blackmore, Richard Dawkins and Daniel Dennett. Inspired by evolutionary theories, meme theory emphasizes the role of imitation and aims at identifying memes, i.e. units that carry cultural ideas, symbols and practices. Our approach, however, draws on a different theoretical background, posthumanist discussion on human/non-human agency in particular.

4 Sampson 2012. See also Nahon and Hemsley 2013. On the definition of the 'viral', see for example Oxford Dictionary of English 2015; Oxford Living Dictionaries. https://en.oxforddiction aries.com/definition/viral. DoI: 10.1093/acref/9780199571123.001.0001 (accessed on 29January 2018).

5 Nahon and Hemsley 2013, xii-xiii. 
digital content in a short time span. The idea of virality has already been applied to the study of the nineteenth century, especially in the study of text reuse in the press. ${ }^{6}$ In this article, we take a somewhat different approach by concentrating not on virality per se but on its essential condition, the idea of infectivity. For us, infectivity is not a metaphor, nor does it imply similarity, as would be the case if we simply compared the dynamics of physical contagiousness to cultural transmission and looked for resemblances. Rather, we argue that particular cultural phenomena have the capacity to become infectious in the same sense as diseases and epidemics do.

The increasing connections and mobility in the early nineteenth century involved unexpected affinities that led to unexpected chain reactions. In what ways did such 'infectious dynamics' occur in the early nineteenth century, an age in which the infrastructure of modern city life, mass media and political participation were beginning to take shape? We argue that the study of infectivity in the early nineteenth century can shed light on embryonic modernity and the emergent potential for change. It is important to note that from the vantage point of human intentions and meaning making cultural infectivity is preconscious. Just as people do not adopt diseases at the very time they become ill, the processes of cultural infection and transmission do not take place on the basis of deliberate action or conscious embracement.

The article draws on several strands of historical scholarship. The literature on modernity has paid particular attention to the nineteenth century, emphasizing the rise of urban cultures at the beginning of the century and the expansion of the public sphere. ${ }^{7}$ During this time of profound change, as pointed out by Marshall Berman, the experience of modernity was often characterized by a feeling of uncertainty. ${ }^{8}$ Social and economic systems went through huge transformations, and during the early decades of the nineteenth century expectations of a new democratic order were extremely acute in different parts of the world. Studies of these processes have been carried out in national and regional contexts for generations, while transnational history, entangled history (histoire croisée, Verflechtungsgeschichte) and cultural transfer studies have focused on various cross-border connections and exchanges. From Benedict Anderson's Imagined Communities (1983) to recent literature on global history there has arisen a growing interest in the cultural, technological and political mechanisms that produced national identities but also carried multiple ideas, sensibilities, visual and rhetorical motifs, goods, services, resources,

6 For example, Ryan Cordell and David A. Smith's Viral Texts project at Northeastern University in Boston, https://viraltexts.org/ (accessed on 6 July 2020). On the concept of virality and its application in the study of nineteenth-century history, see Salmi 2018, 71-79.

7 Benjamin 1999; Eley 1992, 289-339.

8 Berman 1982, 21, 31, 103, 121. See also Blix 2006, 51-71. 
narrative structures and news from one place to another. ${ }^{9}$ Unlike the comparative approach, research on cultural transfer emphasizes the integration of foreign cultural elements into a culture defined as native. Motives and circumstances of importation replace a perspective emphasizing exportation and influence..$^{10}$ One way to scrutinize the aspects of reception, dispersion and application in this context, as we do, is to focus on processes of transmission and infection.

In Finnish research, it is still common to see the emergence of modernity in the social, cultural and technological innovations that took place in the Grand Duchy during the latter half of the nineteenth century. From this point of view, the growth of heavy industry and city infrastructure, the rise of social movements and political parties and the enhancement of media technology are the essential milestones. The first decades of the nineteenth century have been seen as a political and governmental stagnation in the shadow of the Russian empire." The political life of the country was overseen by the Imperial Senate, a body of civil servants that followed the orders of the establishment in St. Petersburg. However, the country also had strong connections with the Baltic Sea region and German-speaking northern Europe and their cultural centres, which makes it a paradigmatic case for studying infectiousness in the past. This is where our agenda comes in. Being a sort of laboratory for transnational dynamics that included romantic and revolutionary ideas, student associations, the growing press and the importance of literature and reading, early nineteenth-century Finland represents an opportunity to scrutinize these processes in detail. Furthermore, a look at the period allows one to understand the countermeasures and the fear felt by the authorities in an unstable situation.

Having introduced our basic idea on embryonic modernity and its importance for the study of early nineteenth-century Finland, we will now examine our subject through three different lenses, starting with social infectivity on a minor scale, exemplified by the unrest caused by students in the streets and the courtyards of Turku. This section will deal with how collective agency was born out of the mutual enthusiasm and affective response of the expanding groups of students during the latter part of the $1810 \mathrm{~s}$. We will then investigate the contagiousness of ideas seen through the lens of the press and its role as a news medium in the $1820 \mathrm{~s}$. In this section, the emphasis is on the news and

9 Anderson 2006; Werner and Zimmermann 2006; Haupt and Kocka 2012; Iriye 2013; Cronqvist and Hilgert 2017 .

$10 \quad$ Middell 2000, 26.

11 In Finnish historiography, the years of 1809-1863 have been characterized by the epithet 'governmental night' (valtioyö, statsnatten), which refers to the fact that the assembly of the representatives of the estates did not have its meetings. See, for instance, Puntila 1947, 459; Edgren-Henrichson 2017, 16-18. 
reports on revolutions and subversive activities in southern Europe. The last section will concentrate on the news about cholera and its rapid spread during the early 1830 . The strong tendency of the newspapers to copy and reuse pieces of information on cholera made the media procedures seem like an epidemic; they were in fact an epidemic in the contemporary media machinery. Through these three lenses we identify and investigate infectious dynamics in early nineteenth-century Finland on three different levels. The information we present is drawn from our scholarship on early nineteenth-century Finland and on primary material comprising printed sources, including letters and archival documents, and on the periodical press, which is available as a digitized collection and which is particularly illuminating from the perspective of infectivity.

\section{3 Student Unrest}

The university in Turku was originally called the Royal Academy. After the annexation of Finland as a Grand Duchy by the Russian Empire in 1809, it became the Imperial University. This name remained until 1828 when the institution was moved to the new capital of the country, Helsinki. As in other European academic milieus, the disturbances caused by unruly students had been, if not regular, at least common in Turku during the seventeenth century and a great part of the eighteenth century. ${ }^{12}$ Yet, by 1808 , at the end of the Swedish period, the detention room of the Academy, the place where badly mannered students were held in custody, had been unused for decades. ${ }^{13}$ However, things were about to change, as in spring 1817 a police station, the first in the whole country, was established in Turku. What aroused anxiety and emotional turbulence among the students was an order allowing them to be interrogated by the police if they became involved in any kind of conflict with non-academic inhabitants of the city. Accustomed to their academic privileges, the students did not acknowledge this but appealed to the old norm that the academic council (Consistorium Academicum) was the right body to deal with that issue. ${ }^{14}$

The imposition on the rights of the students on the one hand and the jurisdiction of the police on the other gave rise to multiple pronouncements and opinions at the university. The new rules made the atmosphere more tense among the students. The first indication of unrest was a spontaneous public

\footnotetext{
12 On student revolts and academic activism during the Middle Ages and early modern period, see Boren 2019, 7-32; Dhondt and Boran 2018, 14-53, 120-135, 222-250.

13 Klinge 1967, 331; Klinge 1989, 63.

14 For further detail, see Soikkanen 2016, 19, 62, 66, 81-82; Tudeer 1914, 285-286.
} 
demonstration by the students on the streets of Turku during Easter 1817. It did not grow to a mass phenomenon, but it was the first public protest in Finland in the modern era, an infectious event that drew people together. One of the participants, Anders Johan Sjögren, wrote about the incident in his diary. In a local restaurant, two separate groups of students were having their supper with wine. Most of the youngsters were noisy and talked about the new situation at the university; after the meal, both groups came together and left the restaurant in a restless mood. Obviously, some of the diners were drunk. From there on, things took an unexpected turn. Every student the group met on the streets of the city was warmly welcomed and asked to join. Thus, step by step, the group grew in number and it began to make noise and gleefully sing songs on the streets. Naturally, the disturbance made by the crowd drew the attention of the inhabitants, and later in the evening a large number of these students were surrounded by the law enforcers and taken to the town guard for further inquiries. However, no one was arrested..$^{15}$

Several weeks later, most of the students signed a petition for more academic freedom. In the next few years, it became usual for the academic council to conduct time-consuming inquiries into the violent behaviour of the students responsible for incidents such as brawls, throwing stones, breaking windows, lifting front gates from their hinges and disturbing military personnel and travellers visiting the city. Even though the tensions caused by the new police force were settled by an imperial rescript towards the end of the 1810 s that allowed the students to keep their privileges, the unrest persisted, flaring up at regular intervals up to the year the university was moved to Helsinki. ${ }^{16}$ The most visible incidents took place in 1817, 1819 and 1821 .

It is quite easy to draw the conclusion that there were several motives and underlying factors behind these disturbances. In many cases, the students were just having fun, with or without alcohol. Occasionally, they had conflicts with the apprentices of craftsmen. There were also disruptions that broke out due to tensions between the students and the Russian troops located in the city in the 1810 and 1820 s. According to the testimonies, some soldiers were violent and provocative, especially when drunk. ${ }^{17}$ In addressing infectious dynamics, which according to our theory are based on imitation, it is essential to consider the ambiguous nature of the students' behaviour. As Anders Johan Sjögren tells in his diary, many students seem to have acted without a clear rationale; they were predisposed to form crowds and become noisy and

\footnotetext{
15 Sjögren, 5-6 April 1817.

16 Tudeer 1914, 286; Klinge 1989, 63; Westermarck 1916, 22-23; Heinricius 1911, 72, 156-163; Gevers and Vos 2004, 276.

17 Heinricius 1911, 72-73; Castrén 1933, 106.
} 
disturbing. Instead of intentions and carefully made plans, there was a preconscious flow of contagious affect and emotions strengthened by imitation. This process could not have been anticipated from beginning to end. Whatever the motives and ideas of those involved, the actual chain of events and the outcomes of the incidents were unforeseen. Whether a noisy demonstration, a violent outburst against Russian soldiers or a body of students marching and singing together, the groups on the streets were usually formed step by step as those already together persuaded other students, passers-by and restaurantgoers to join them. ${ }^{18}$ Naturally, the number of people varied, but the social mechanics of imitation and contagion were at work.

In October 1819, a bigger group of approximately fifty men formed very quickly after some students manhandled a Russian soldier on the bridge in the city centre and then marched to the main guard of the Russian troops. ${ }^{19}$ What was at stake in incidents such as these was prestige. The students competed with the Russian soldiers for visibility on the streets and thus control of the city space. In Uppsala in Sweden, the same motive but without a military opponent came into play as students gathered to march through the streets singing and shouting. Despite the controlling aspect, choir singing in Turku was usually a very peaceful activity. Sometimes the marches extended to the borders of the city. ${ }^{20}$

Because the preconscious flow of emotional energy was corporeal, diffuse and ambiguous rather than based on deliberate decisions and meaning making, it is little wonder that it aroused conflicting views in contemporaries and later generations alike. For instance, the amateur cultural historian Gustaf Heinricius who was active at the beginning of the twentieth century and who published extensively on the academic life of early nineteenth-century Turku, commented that during those days the government in St. Petersburg made a big fuss about harmless episodes in the Grand Duchy of Finland. ${ }^{21}$ He thought that those in power overestimated the activities of drunken or otherwise unruly students and without good grounds saw the unrest as an expression of revolutionary attitudes. On the contrary, Finnish historian Matti Klinge noted it was obvious that the student disturbances, besides being youthful entertainment, were also a way of expressing political ideologies. ${ }^{22}$ In the long run, this dispute is bound to remain unsolved; there are too many ambiguous details

18 For further detail, see Sarjala 2020, 148-150, 203-204; Andersson 1921, 124-131. On microimitations and subrepresentational flows of affect as basic forces of contagions among bodies and in networks, see Sampson 2012, 6-8, 40, 185.

19 Castrén 1933, 109-110; Heinricius 1911, 77-78.

20 Klinge 1967, 384-385; Heikinheimo 1932, 264-266; Stenius 1996, 287, 289.

21 Heinricius 1911, 102.

22 Klinge 1989, 82-83. 
and aspects in those incidents. Even though some enthusiastic students might have been good at organizing or leading the crowds, it is still very hard to find empirical evidence of planning or engineering violent activities and demonstrations on the streets of Turku.

Whether harmless episodes or political statements, Emperor Alexander I of Russia was concerned. Having lost his temper over the unrest in Turku, in October 1821 he ordered the guards of the Russian troops in the city to keep their rifles loaded. The Emperor saw it as a grave infringement upon law and order that the students had forced firearms from the hands of the Russian soldiers. In these new circumstances, the local administrators were afraid that living in the city was about to become highly dangerous, but the Emperor withdrew his order in December of the same year after things seemed to have settled down. ${ }^{23}$ However, they did not, as a few days later a mentally disturbed student, Johan Emanuel Gadolin (1801-71), assaulted the Swedish-born professor Israel Hwasser (1790-1860). Armed with a sword, Gadolin hit Hwasser on the head in his house in December 1821. The injuries were not severe, and the professor recovered in a few months. The academic council investigated and put the perpetrator under surveillance for the rest of his life. The official records of the case were published in two volumes in $1822 .{ }^{24}$ The incident attracted public interest in Turku and St. Petersburg.

It is worth noting that the recently appointed Vice-Chancellor Johan Fredrik Aminoff (1756-1842), the highest local administrator of the Imperial University of Turku, gave an inaugural speech at the opening festivities that autumn in which he advised the younger audience members to be cautious about the heresies that had given rise to dangerous rumblings in other countries. ${ }^{25}$ Evidently, Aminoff was referring to the revolutionary ideas and patriotic sentiments of the German student leagues, Burschenschaften, which were also known in Turku. The fact that those involved were aware of the subversive ideas in different corners of Europe was one of the main factors which intensified and mobilized the affective response of both students and the academic or civil establishment. For instance, a central element causing sensation in the Hwasser-Gadolin case was the fact that many citizens of Turku found a parallel between the assault and the murder of playwright August von Kotzebue (1761-1819) that occurred in Mannheim several years earlier. ${ }^{26}$ Some students in Turku allegedly admired the murderer of Kotzebue, Karl Sand (1795-1820),

\footnotetext{
23 Castrén 1933, 120-122; see also Soikkanen 2016, 92.

24 Heinricius 1911, 120-122; Rättegångs-Handlingar 1822; Soikkanen 2016, 87-88.

$25 \quad$ Klinge 1967, 390, 392-393; Klinge 1989, 82.

26 Heinricius 1911, 122.
} 
who had belonged to the Jena Burschenschaft and whose victim was considered a traitor, a spy writing reports to Emperor Alexander I of Russia. ${ }^{27}$ Whatever the motives of Johan Emanuel Gadolin, his attack on Hwasser was seen as an unsuccessful version of the deadly incident abroad. Vice-Chancellor Aminoff, among others, saw Gadolin's act in that light. He even expected to be the next victim and bid his relatives farewell when visiting Helsinki in the summer of 1822. To Aminoff's great annoyance, the academic council tried to avoid any comparison to Kotzebue's murder, evidently in order to quiet discussion about the political aspects of the assault. ${ }^{28}$ Infectious dynamics worked on two levels in this case, by means of affective response on one hand and by means of discursive meaning making on the other.

In this section, the focus shifts to the emerging Finnish press and its role in disseminating news on political unrest and revolutionary sentiments in Europe. Ever since the French Revolution of 1789 , the possibility of the spread of revolutionary sentiments was embedded in the understanding of 'revolution'. The will to propagate French republican liberty beyond the borders of France was incorporated in the revolutionary rhetoric. ${ }^{29}$ This is what revolutionary France did in practice; it fought for its aims in the revolutionary wars and in the republics established in the conquered areas. Thus, infectivity was the second nature of revolution. What kind of resonance did the revolution have in early nineteenth-century Finland? This section concentrates on the visibility of international information flows and the dissemination of revolutionary news in the Finnish newspapers during the early 1820 s before the expansion of the Finnish press. At this point, only a handful of newspapers were published in the Grand Duchy. Following the main argument of this article, the aim in this section is to show how circulating news opened views for an alternative order of things, a new order brought about by revolutionary actions.

In the Finnish territory, newspaper publishing started in Swedish in 1771 when the first paper Tidningar Utgifne af et Sällskap i Åbo came out in Turku. Until the establishment of the Grand Duchy of Finland, the Turku-based paper was a local or regional publication concentrating on literary matters. In 1810, the paper was renamed Åbo Allmänna Tidning (from 1820 onwards Finlands

27 Klinge 1967, 402; on Kotzebue's murder and its background, see Williamson 2000.

28 Heinricius 1911, 141; Klinge 1967, 402; see also Rättegångs-Handlingar 1822, passim.

29 Lerner 2004, 53-54. 
Allmänna Tidning) and until 1820 it would be the only paper in the Grand Duchy to publish foreign news in addition to official announcements. For example, during Napoleon's war campaign in Russia in 1812, the paper published bulletins reporting the ongoing hostilities from the Russian point of view. When Napoleon was defeated in the spring of 1814 , the paper saluted this news with joy. ${ }^{30}$

However, the fall of Napoleon did not bring peace and stability to Europe. Although the European system of congresses, starting with the Congress of Vienna in 1814-1815, aimed at stabilizing the continent and maintaining the existing social order, the early 1820 s continued to be marked by political unrest and revolts, particularly on the Italian peninsula and within the Ottoman Empire. In Spain the revolution of 1820 led to years of Trienio Liberal, a period of liberal rule. ${ }^{31}$ During the early 1820 s, there was a clear increase in the international news published in Finlands Allmänna Tidning. ${ }^{32}$ One reason for this was the fact that the paper had started to cover the political upheavals in Europe. In what follows, we examine this practice in more detail.

During the spring of 1820 , Finlands Allmänna Tidning began to publish reports on the events in Spain, where King Ferdinand (Fernando) viI had been forced to accept a liberal constitution and practically hand over his power to the liberal government. The Finnish paper called this coup a revolution. Moreover, Finlands Allmänna Tidning began to deliver news on the revolutionary movement in Southern Italy. The first report was published on 14 August 1820, based on information given by an anonymous source in Naples. According to the account, the revolution had begun with protests calling for a liberal constitution (the model being the Spanish constitution of 1812) in the towns of Nola and Avellino near Naples and quickly spread to neighbouring areas. Within the following days, a crowd reached Naples, where the city declared the adoption of a model of the Spanish constitution. ${ }^{33}$ The Finnish news report included information on the further advance of the revolutionary troops in Italy. Information on this sudden uprising was 'spreading like lightning', the paper stated. ${ }^{34}$ It took more than a month, however, for the news to arrive in Finland.

How did the news of the Neapolitan revolution spread to the Finnish territory? News agencies did not exist before the 1830s. Furthermore, there was no telegram network, as the first such service began on the European continent

30 Paasivirta 1978, 55, 58; Rantala 2019, 721-736.

31 On the congress system, see Jarrett 2013.

32 Apunen 1970, 50-54.

33 Davis 2006, 299-301.

34 Finlands Allmänna Tidning, August 14, 1820, 1-2. All references to the Finnish newspapers, The National Library of Finland Digital Collections, https://digi.kansalliskirjasto.fi/. 
only in the 1850 os $^{35}$ The revolutionary events in $1848-1849$ have been interpreted in terms of a chain reaction; uprisings spread from one country to another and the newspapers followed the incidents closely. Not only did the information travel fast due to new communication networks such as railways, in the 1840 s there were also many more publications reporting the events. ${ }^{36} \mathrm{Com}-$ pared to the late 1840 s, in the early 1820 s the preconditions for the quick spread of news were still modest.

In most cases, news travelled by post carriages and ships, before being disseminated via newspapers; thus, the press created transnational chains for the spread of news. The editor of the official Finnish paper used various foreign newspapers, including French and British ones, as sources when copying and translating foreign news. ${ }^{37}$ In the case of the outbreak of the Neapolitan revolution, the first news reports were published in British newspapers on 21 or 22 July $1820 .{ }^{38}$ It would have been possible for the Finnish paper to use these news reports as its source. In this case, however, the source seems to have been the Swedish Stockholmsposten, which reported the same news on 2 August, based on a report that had been sent from France to London. ${ }^{39}$

Reports about the Italian revolution appeared quite regularly in the Finnish paper during the following months. Readers were informed, for example, of the meaning of carbonari, literally referring to charcoal burners, an expression used to describe the revolutionaries. ${ }^{40}$ At this point there was no formal censorship in Finland; this was introduced in $1829 .^{41}$ In practice, publishing activities were monitored, however, and Finlands Allmänna Tidning avoided taking any clear stand on political issues. Copying news from foreign papers was a way for the paper to deliver information on politically sensitive topics. Apart from British, French and Swedish newspapers, the editor of Finlands Allmänna Tidning utilized German and Austrian newspapers as well as German and French-language newspapers published in St. Petersburg. The perspective of

35 Rantanen 1997, 6o9, 612.

36 von Strandmann 2000, $1-3$.

37 Tommila 1988, 110-112.

38 At least The Morning Chronicle and The Morning Post reported on the outbreak of the revolution on 21 July. The next day The Morning Chronicle referred to a letter dated in Naples 6 July including information on the course of events. The Morning Chronicle, July 21, 1820, 3; The Morning Chronicle, July 22, 1820, 2; The Morning Post, July 21, 1820, 3. Gale Primary Sources. British Library Newspapers, Part I: 1800-1900. Online database (accessed on 7 July 2020).

39 Stockholmsposten, August 2, 1820, 2-3. Svenska Dagstidningar Database, https://tidningar .kb.se/ (accessed on 7 July 2020).

40 Finlands Allmänna Tidning, August 25, 1820, 1-2.

$41 \quad$ Nurmio 1934. 
the latter source was different from the other papers mentioned, as Russia, Prussia and Austria formed the Holy Alliance, the heart of European reactionary politics.

During 1821, the Finnish paper published many reports with information on the meetings of the European sovereigns concerning the Neapolitan revolution. These meetings took place in Troppau (Opava) in late 1820 and in Laibach (Ljubljana) in early 1821 . One outcome was a military intervention by Austrian troops in Italy. ${ }^{42}$ Furthermore, different statements communicating the sentiments of the meetings were circulated in newspapers across the European continent. The members of the Holy Alliance in particular expressed great concern over the possible spread of the revolutionary spirit. Finlands Allmänna Tidning published these kinds of reports, again based on other European newspapers, and thus passed on the anxiety over the state of affairs in Europe. For example, at the beginning of February 1821 the Finnish paper published extracts from a statement in which the members of the Holy Alliance condemned the actions of the Neapolitan revolution..$^{43}$ From 1820 onwards there was also a Finnish-language newspaper in Finland that provided information on the Italian uprising. On 17 February 1821, for example, the paper reported on the Laibach meeting, stating that it was feared the uprising might spread. ${ }^{44}$ This way, Finnish-speaking readers were informed of the unstable situation in Continental Europe.

Soon after the end of the Italian uprising, European newspapers began reporting on the Greek uprising in the Ottoman Empire. This news was also published in the Finnish papers in both Swedish and Finnish. The tone of the reports was enthusiastic. ${ }^{45}$ This turbulence in European politics coincided with the turbulence in Turku. It can be argued that due to the revolutionary movement in Southern Europe, the student unrest in Turku was potentially dangerous; therefore, officials took it very seriously. The closure of the Turku-based journal Åbo Morgonblad in 1821, for example, should be seen in the wider context of European politics, although the paper did not comment on the incidents in Southern Europe. However, Åbo Morgonblad called for an open discussion on contemporary issues. The editor of the journal Adolf Ivar Arwidsson (1791-1858) was considered a student leader and troublemaker—some officials explicitly called him a carbonari. ${ }^{46}$

\footnotetext{
42 Davis 2006, 311-314.

43 Finlands Allmänna Tidning, February 1, 1821, 1-2.

44 Turun Wiikko-Sanomat, February 17, 1821, 25-26.

45 See, for example Rantala 2019, 10.

46 Castrén 1951, 363, 381; Kalleinen 2017, 148.
} 
By spreading news on revolutionary actions, the press helped create and foment the infectivity of the revolution. Not only did it amplify the phenomenon by communicating it, but the press also was a transmitter of revolutionary sentiment. This infectiousness was visible in Finland, although on a modest scale. Earlier studies have emphasized mid-nineteenth-century political events, first and foremost the revolutionary year of 1848 and the Crimean War of $1853^{-1856 \text {, }}$ as vital cornerstones in the development of the Finnish press in terms of international news flows. ${ }^{47}$ Compared to the 1840 s and 1850 s, the scale of Finnish newspaper publishing was low in the early 1820 . Yet the necessary connections for the circulation of information did exist. Although the practice of copying material from one paper to another can be considered a less ambitious journalistic activity, in terms of interconnectedness it was all that was needed. Regardless of the attitudes towards the revolutions, the topic entered the emerging Finnish press through the news clips. In this sense, the infective nature of revolution reached Finland.

Our third example of embryonic modernity and the infectious dynamics in early nineteenth-century Finland is closely connected with the second one. Newspapers were an arena for transborder information flows, although their spread remained limited in early nineteenth-century Finland. However, they epitomized the modern media expanding elsewhere in Europe. The news itself was transregional, moving across borders via steamships and later railways. It travelled in an ever-accelerating rhythm, thanks also to the emerging telegraph lines from the 1840 on onwards. Other things were on the move too, from industrial products to invisible pathogens that caused widespread pandemics. The nineteenth century saw many disastrous waves of infectious diseases, particularly influenza ${ }^{48}$ and cholera. ${ }^{49}$

Caused by the bacterium vibrio cholerae, cholera had a particularly serious presence in the nineteenth century. There were actually six pandemics that together covered almost the whole century. The first global pandemic spread gradually from India to Southeast Asia, the Middle East, Europe and Eastern Africa between 1817 and 1824. The second pandemic took place between 18271835, reaching Europe and North America. In the subsequent years, cholera

\footnotetext{
47 Tommila 1988, 223; Tommila 1963, 76-8o.

48 Honigsbaum 2014.

49 Hamlin 2009.
} 
appeared also in North Africa and South America. It spread via trade routes and human migration, and its expansion could be seen as an indication of the increasing ties between different corners of the world. This was also noticed by the English physician John Snow, who in 1849 published his essay On the Mode of Communication of Cholera in which he argued that cholera was obviously 'propagated by human intercourse..$^{50}$ Cholera became a cultural infection, the fear of which was transmitted through the emerging media network and aroused unrest among the public.

In the 183os, cholera aroused fear everywhere in Europe. Having hit the biggest urban concentrations, such as Paris, it was soon expected to affect more remote areas. ${ }^{51}$ Finland was first hit by cholera through the press, before any actual physical infection had been recorded. The first mention was in the official newspaper Finlands Allmänna Tidning on 15 September 1820. The newspaper devoted many pages to listing different causes of death, from nervous strokes to plagues. This listing included 'a disease called Cholera' which manifested itself as 'violent vomiting with severe exhaustion'.52 The second mention was on 23 April 1822 in a news report on recent incidents in the Ottoman Empire. The lethal presence of cholera morbus was mentioned in the conclusion to a statement that 100,000 people had died of the disease in Shiraz and the surrounding area (in present-day Iran). ${ }^{53}$

It took only a few years for cholera to spread from Asia to Europe and then to Finland. The first half of the century saw two epidemics, in the 1830 and the 1850s. The period was characterized by a consciousness of the disease coming unavoidably closer every day. ${ }^{54}$ The press participated in creating anxiety, as people knew by reading the newspapers what was happening and could probably foresee a time when cholera would hit local towns. In this sense, the pandemic increased the awareness that a modern world involved interdependence between different regions, between bigger cities and smaller towns and between centres and peripheries. The disease hit urban centres harder than rural areas and thus seemed hostile towards the rising urban culture. In the 1830s, cholera seemed to be approaching Northern and Western Europe from the east. On 30 September 1830, Finlands Allmänna Tidning reported from St. Petersburg that cholera had been observed on both sides of the Caucasus in Astrakhan, Orenburg and Saratov as well as in the lands of the Don Cossacks.

50 Snow 1849,5 .

$51 \quad$ Kudlick 1996.

$5^{2}$ Finlands Allmänna Tidning, September 15, 1820, 8.

53 Finlands Allmänna Tidning, April 23, 1822, 4.

54 On the spread of cholera, see for example Hamlin 2009, $5^{2-55}$. 
Every effort was made to prevent its expansion. ${ }^{55}$ This proved to be too optimistic, however. By 1831, cholera was present in all major Russian cities and soon spread to Prussia and Poland. By the end of the year, cholera had spread across all of Europe, including England. ${ }^{56}$

The spread of the disease aroused fear everywhere and was accompanied by an abundance of news. There were many news reports on cholera that spread in an infectious manner across borders. One of these reports told the story of Dr Leo, a Polish physician who was argued to have invented a cure for the disease. This news was reported in Finland on 6 July 1831 in Åbo Underrättelser. ${ }^{57}$ The Warsaw-based Dr Leo had developed a therapy for cholera based on magisterium bismuthi. ${ }^{58}$ This homeopathic treatment was also mentioned in the Åbo Underrättelser report. The story continued three days later in a longer article titled 'Cholera besegrad' (Cholera defeated), copied from the Swedish magazine Minerva, which stated that the text was originally published in the 'Warsaw city paper. ${ }^{59}$ Current digital newspaper repositories show how quickly this positive news actually spread. After the original publication of the news in Warsaw, Dr Leo's findings were reported in Berlin on 20 June 1831. From there the news spread to the south, north and west. The news was published in London on 29 June, in Stockholm on 1 July, in Sheffield on 2 July, in Drammen, Norway on 7 July and in Linz, Austria on 11 July. ${ }^{60}$ The optimistic news found fertile soil in the shadow of a serious catastrophe. Soon, the news was understood to be only the expression of a desperate hope for a turn of events.

In the political climate of the early 1830 , cholera was surrounded by rumours and speculation. Minorities and foreigners, authorities and enemies were regarded as responsible for the contamination. ${ }^{61}$ These mixed feelings were deepened by the revolutionary activities in France and Poland and by the military campaigns in Prussia, Poland and Russia. In France, cholera was represented as a monster from the barbarian East that would soon threaten Western civilization. ${ }^{62}$

The news of Dr Leo's treatment spread with the expansion of the disease. When the news was published in Turku on 6 July 1831, cholera had already

Finlands Allmänna Tidning, September 30, 1830, 1.

56 Ross 2015, 9-12.

57 Åbo Underrättelser, July 6, 1831, 3 .

58 Ross 2015, 66.

59 Åbo Underrättelser, July 9, 1831, 2.

$60 \quad$ Salmi 2018.

61 Hamlin 2009, 51.

62 Kudlick 1996; Hamlin 2009, 55; Ross 2015; Salmi 2018. 
hit Finland. It was first noticed in the city of Vyborg, situated on the Karelian Isthmus near St. Petersburg. By the time the news was published both journalists and readers knew that cholera was very near and that it would soon hit Helsinki and Turku. Indeed, the disease appeared in both cities in August. ${ }^{63}$ As already pointed out, the volume of the press was quite limited in Finland in 1831. There were only eight newspapers published, and they were printed in four cities: Helsinki, Oulu, Turku and Vyborg. While Helsinki, Turku and Vyborg are situated on the southern coastline, Oulu is in the north on the shores of the Gulf of Bothnia.

Although the capacity of the press was limited, there was a wave of cholera news. This is exemplified by the number of mentions of cholera in the press. The digitized newspapers at the National Library of Finland show that cholera was mentioned only 21 times in 1830, but no less than 412 times in $1831 .{ }^{64}$ This shows the interest of the press in following the spread of the disease and in reporting on official precautions to prevent the catastrophe. To be sure, newspapers reached only a small part of the population of the Grand Duchy of Finland, but at the same time the press became a breeding ground for the mechanisms of infectivity. In the early nineteenth century, infectivity was fuelled by cross-border flows and transnational networks. Being part of the Russian Empire, Finland had close ties with St. Petersburg and therefore saw an increasing amount of traffic in terms of both people and goods. These ties fostered the infectiousness of the disaster, as they did elsewhere in Europe. At the same time, this infectiousness led to the organization of public health. It became obvious that hygiene guidelines were needed. In his book Contagion and the State in Europe, 1830-1930, Peter Baldwin describes how the spread of infectious diseases in the nineteenth century was entangled with the development of the modern state. ${ }^{65}$ This involved not only the question of public health services but also definitions regarding the rights of individuals, which sometimes had to be restricted to minimize the spread of disease. In this sense, cholera infections in early nineteenth-century Finland had a role in the construction of a modern state and in increasing awareness of the many bonds that tied regions together.

\footnotetext{
63 Vuorinen 2002, 124-126.

64 Digital Collections of the National Library of Finland, https://digi.kansalliskirjasto.fi/ (accessed on 20 November 2019).

65 Baldwin 1999, $1-36$.
} 
This article focused on the formation of modern mass phenomena in early nineteenth-century Finland. It concentrated on student unrest in Turku, news of revolutionary activities circulated by the emerging newspaper business and the spread of cholera that was publicized in the press. All these phenomena were based on the dynamics of infectivity, and they were limited socially and geographically. Academic life was centred in and around Turku and newspapers were published in no more than four cities and had a small print run. Still, they offer a view of the contagiousness that enabled the expansion of these small embryos and their socio-material mechanisms in the contemporary world.

The student unrest was transmitted via two levels of infectious dynamics: by affective response, which was corporeal, and by discursive meaning making. While this unrest was geographically limited, similar subversive sentiments were spread on a much larger scale through the transnational networks of the press. Thus, the early Finnish newspapers exemplified the connectivity that enabled the infectious flow of information. Its contagiousness was also characterized by its potential to cross borders. The example of the spread of information about cholera and the emotional turbulence it provoked is built on these elements of effective expansion. To be sure, the disease itself was contagious, but its cultural and social ramifications were also infectious; thus, cholera had a huge impact everywhere in Europe. In addition, all three examples had counter-effects or involved reciprocity. Finland was part of the Russian Empire where student unrest and the spread of revolutionary ideas were followed with great concern. Authorities had to find ways of fighting this contagiousness and preventing its uncontrolled expansion. In the case of cholera, this is obvious on two levels. After the first wave of the disease in Finland in 1831, both state officials and journalists became conscious of the ambiguous role of the press. The more that was written about cholera, the more fear there was. At the same time, it was important to increase awareness of the disease and give advice on how to prevent infection.

In the introduction, we used the term embryonic modernity. The early nineteenth century was an incubation period of modern culture showcased by the three phenomena we have elaborated concerning Finland. The word 'embryonic' refers to the idea of potentiality. An embryo is not structured but is in a state of formation. It has various trajectories for development, but these are by no means clear, predestined or ready-made. Some elements may develop in different rhythms than others, and some elements may just fade away. Our three elements illustrate three separate processes of differentiation on the 
basis of a common socio-material mechanism, that of contagion. They all had their own rates of progression and dynamics. Therefore, the history of modernity is a story of situated, regionally specific processes. In Finland, for example, the development of the press was different compared to Continental Europe, and the censorship conditions under the Russian authorities sometimes made it difficult to develop information networks further. The actual growth was realized from the 1860 os onwards, many decades after the wave of cholera news in the early 1830 . Something similar can be said about the student unrest and student demonstrations in Finland. In Helsinki, they broke out again in $183^{1}$ and 1849 , provoked by the political and social turbulence on the Continent, but in a more modest way than in many other places in Europe.

In the early nineteenth century, it is possible to identify infectious phenomena, as we have done, and analyse their dynamics. These socio-material mechanisms were conditions for the realization of many later developments. The justification of the study of infectious dynamics does not derive, however, from what later proceedings brought into the limelight or what has proven to be important in retrospect. Rather, its significance is in the acknowledgment of the historical presence of the many potentialities that existed in the past. In terms of our subject, they have contributed to the constitution of various networks and consolidated the sense of interdependence between larger social formations emerging in the course of the nineteenth century.

\section{About the Authors}

Hannu Salmi is Professor of Cultural History at the University of Turku, Finland, and was nominated Academy Professor for the years 2017-2021. His research interests focus on the cultural history of the nineteenth century, media and music history, digital history and the history of emotions and the senses. He is also the founding member of the Turku Group for Digital History. He is the author of many books, including Nineteenth-Century Europe: A Cultural History (Polity, 2008), What is Digital History? (Polity, 2020) and the editor of Routledge Companion to Cultural History in the Western World (with Alessandro Arcangeli and Jörg Rogge, 2020).

Jukka Sarjala is an Adjunct Professor (Docent) in the School of History, Culture and Arts Studies at the University of Turku, Finland. His research interests focus on the cultural history of the nineteenth century and its intellectual undercurrents in Europe, especially the history of early Romanticism. His output covers monographs, textbooks and articles, including Music, Morals, and the 
Body: An Academic Issue in Turku, 1653-1808 (Finnish Literature Society, 2001) and a co-edited anthology Travelling Notions of Culture in Early NineteenthCentury Europe (Routledge, 2016).

Heli Rantala is a Postdoctoral Research Fellow in the Department of Cultural History at the University of Turku. Her research interests lie in the field of nineteenth-century cultural history, with a special focus on northern Europe and Finland. She has published in Finnish and English on various topics in this field, including the history of historical thought, history of concepts and the Finnish press history.

\section{References}

Anderson, Benedict. Imagined Communities: Reflections on the Origin and Spread of Nationalism (London: Verso, 2006, orig. 1983).

Andersson, Otto. Johan Josef Pippingsköld och musiklivet i Åbo 1808-1827 [Johan Josef Pippingsköld and the Musical Life in Turku 1808-1827] (Helsingfors: Holger Schildts förlagsaktiebolag, 1921).

Apunen, Osmo. Hallituksen sanansaattaja. Virallinen Lehti - Officiella Tidningen 18191969 [The Messenger of the Government: the Official Newspaper 1819-1969] (Helsinki: Valtion painatuskeskus, 1970).

Baldwin, Peter. Contagion and the State in Europe, 1830-1930 (Cambridge: Cambridge University Press, 1999).

Benjamin, Walter. The Arcades Project, trans. Howard Eiland and Kevin McLaughlin (Cambridge, MA: Harvard University Press, 1999).

Berman, Marshall. All That Is Solid Melts Into Air: The Experience of Modernity (New York: Simon and Schuster, 1982).

Blix, Göran. "Charting the 'Transitional Period': The Emergence of Modern Time in the Nineteenth Century." History and Theory 45 (2006), 51-71.

Boren, Mark Edelman. Student Resistance. A History of the Unruly Subject, $2^{\text {nd }}$ ed. (New York: Routledge, 2019).

Castrén, Liisa. Adolf Ivar Arwidsson isänmaallisena herättäjänä [Adolf Ivar Arwidsson as a Patriotic Awakener]. Historiallisia tutkimuksia Xxxv (Helsinki: Finnish Historical Society, 1951).

Castrén, Liisa. "Turun ylioppilaat ja venäläinen sotaväki 1810-ja 1820-luvuilla” [The Students of Turku and the Russian Military in the 1810 and $1820 s]$. Historiallinen Aikakauskirja 31 (2) (1933), 106-123.

Cronqvist, Marie, and Christoph Hilgert. "Entangled Media Histories: The value of Transnational and Transmedial Approaches in Media Historiography." Media History 23 (1) (2017), 130-41. DOI: 10.1080/13688804.2016.1270745. 
Davis, John A. Naples and Napoleon: Southern Italy and the European Revolutions (1780186o) (Oxford: Oxford University Press, 2006).

Dhondt, Pieter, and Elizabethanne Boran, eds. Student Revolt, City, and Society in Europe. From the Middle Ages to the Present (New York: Routledge, 2018).

Edgren-Henrichson, Nina. "Politiskt liv med förhinder" [Political Life with Obstacles]. Källan 24 (2) (2017), 16-22.

Gevers, Lieve, and Louis Vos. "Student movements." In A History of the University in Europe. Volume III: Universities in the Nineteenth and Early Twentieth Centuries (1800-1945), ed. Walter Rüegg (Cambridge: Cambridge University Press, 2004), 269-361.

Eley, Geoff. "Nations, Publics, and Political Cultures: Placing Habermas in the Nineteenth Century." In Habermas and the Public Sphere, eds. Craig J. Calhoun (Cambridge, MA: Harvard University Press, 1992), 289-339.

Hamlin, Christopher. Cholera: The Biography (Oxford: Oxford University Press, 2009).

Haupt, Heinz-Gerhard, and Jürgen Kocka, eds. Comparative and Transnational History: Central European Approaches and New Perspectives (New York: Berghahn Books, 2012).

Honigsbaum, Mark. A History of the Great Influenza Pandemics: Death, Panic and Hysteria, 1830-1920. International Library of Cultural Studies 30 (London: I. B. Tauriis, 2014).

Heikinheimo, Ilmari. “K. A. Gottlundin osuus suomalaisen ylioppilaslaulun alkuvaiheisiin" [K. A. Gottlund's Impact on Early Student Singing in Finland]. Historiallinen Aikakauskirja 30 (4) (1932), 253-266.

Heinricius, G. Skildringar från Åbo Akademi 1808-1828. Med 46 afbildningar [Portrayals of the Academy of Turku 1808-1828. With 46 images] (Helsinki: The Society of Swedish Literature in Finland, 1911).

Iriye, Akira. Global and Transnational History: The Past, Present, and Future (Basingstoke: Palgrave Macmillan, 2013).

Jarrett, Mark. The Congress of Vienna: War and Great Power Diplomacy after Napoleon (London and New York: I. B. Tauris, 2013).

Kalleinen, Kristiina. Suuriruhtinaskunnan etuvartiossa. Ministerivaltiosihteeri R. H. Rehbinder Suomen etujen puolustajana Pietarissa 1811-1841 [In the outpost of the Grand Duchy. Secretary of State R. H. Rehbinder as a defender of Finland's interests in St. Petersburg 1811-1841] (Helsinki: Finnish Literature Society, 2017).

Klinge, Matti. "Turun ylioppilaskunta 180o-luvun alussa. Yhteispyrkimyksiä ja aatevirtauksia" [Student Corporation in the Early 19th Century in Turku: Joint efforts and ideas]. Historiallinen Arkisto 61 (1967), 296-429.

Klinge, Matti. Keisarillinen Aleksanterin Yliopisto 1808-1917 [The Imperial Alexander University 1808-1917] (Helsinki: Otava, 1989).

Kudlick, Catherine J. Cholera in Post-Revolutionary Paris: A Cultural History (Los Angeles: University of California Press, 1996). 
Lerner, Mark H. “The Helvetic Republic: An Ambivalent Reception of French Revolutionary Liberty." French History 18 (1) (2004), 50-75.

Middell, Matthias. "European History and Cultural Transfer." Diogenes 48 (1) (2000), 23-30.

Nahon, Karine, and Jeff Hemsley, Going Viral (Cambridge: Polity, 2013).

Nurmio, Yrjö. Suomen sensuuriolot Venäjän vallan alkuaikoina vv. 1809-1829 [The Censorship Conditions in Finland in the Early Days of Russian Rule 1809-1829] (Porvoo: WSOY, 1934).

Osterhammel, Jürgen. The Transformation of the World: A Global History of the Nineteenth Century (Princeton NJ: Princeton University Press, 2014).

Oxford Dictionary of English, 3rd online edition (Oxford: Oxford University Press, 2015). DOI: 10.1093/acref/9780199571123.001.0001.

Paasivirta, Juhani. Suomi ja Eurooppa. Autonomiakausi ja kansainväliset kriisit 1808-1914 [Finland and Europe. The period of autonomy and international crises 1808-1914] (Helsinki: Kirjayhtymä, 1978).

Puntila, L. A. "Yleisen mielipiteen muodostuminen Suomessa 186o-luvulla" [The Formation of Public Opinion in the 1860 s in Finland]. Historiallinen Arkisto $5^{2}$ (1947), 455-521.

Rantala, Heli. “Global 'Revolution' in the Early Nineteenth-century Finnish Press." History of European Ideas 45 (5) (2019), 721-36. DoI: 10.1080/01916599.2018.1558908.

Rantanen, Terhi. "The Globalization of Electronic News in the 19th Century." Media, Culture \& Society 19 (4) (1997), 605-620.

Rättegångs-Handlingar, rörande den emot Medicinae Practicae Professoren vid Kejserliga Universitetet $i$ Åbo Doctor Israël Hwasser af Studeranden dersammastädes Johan Emanuel Gadolin d. 10:de December 1821, i Professorens egne rum, med blottad värja, öfvade våldsgerning [Trial Documents, Concerning the Medicinae Practicae Professor at the Imperial University of Turku Doctor Israël Hwasser, on the Violence Practiced by the Student Johan Emanuel Gadolin on 10 December 1821 in the Professor's Own Room]. 2 vols. (Åbo: Bibel-Sällskapets Boktryckeri, 1822).

Ross III, Richard S. Contagion in Prussia, 1831: The Cholera Epidemic and the Threat of the Polish Uprising (Jefferson, NC: McFarland, 2015).

Salmi, Hannu. "Viraalisuus - kulttuurihistoriallinen näkökulma" [Virality - The cultural historical perspective]. Niin \& Näin (1) (2018), 71-9.

Salmi, Hannu. Viral Culture and the Fear of Cholera in Finland, 1831-1854. Zenodo, October 2018, DOI: 10.5281/zenodo.1475948.

Sampson, Tony D. Virality: Contagion Theory in the Age of Networks (Minneapolis: University of Minnesota Press, 2012).

Sarjala, Jukka. Turun romantiikka. Aatteita, lukuvimmaa ja yhteistoimintaa 1810-luvun Suomessa [Turku Romanticism: Ideas, Passion for Reading and Collaboration in the 1810s in Finland] (Helsinki: Finnish Literature Society, 2020). 
Savolainen, Panu. Teksteistä rakennettu kaupunki. Julkinen ja yksityinen tila turkulaisessa kielenkäytössä ja arkielämässä 1740-1810 [A Textually Built City: Public and private space in linguistic practices and everyday life in Turku, 1740-1810] (Turku: Sigillum, 2017).

Sjögren, Anders Johan. Allmänna Ephemerider 1806-1855 [diary]. National Library of Finland, Manuscript Collection, Anders Johan Sjögren's archive (Coll. 209).

Snow, John. On the Mode of Communication of Cholera (London: Wilson and Ogilvy, 1849).

Soikkanen, Timo. Turun poliisi 200 vuotta. Osa I: Suomalaisen poliisin synty ja Turun poliisilaitos 1816-1918 [The Turku Police 200 Years. Part I: The Birth of the Finnish Police and the Turku Police Department 1816-1918.] (Turku: The Police of the Southwest Finland, 2016).

Stenius, Henrik. "Körens röst. Den profana körsången som forum för den allmänna opinionen" [The Choir's Voice: The profane choral song as a forum for public opinion]. In Boken om Vårt Land 1996. Festskrift till Professor Matti Klinge 31.VIII.1996, eds. Kerstin Smeds, Rainer Knapas and John Strömberg (Helsingfors: Otava and Söderström \& Co., 1996), 286-296.

Strandmann, Hartmut Pogge von. "1848-1849: A European Revolution?". In The Revolutions in Europe 1848-1849: From Reform to Reaction, eds. R. J. W. Evans and Hartmut Pogge von Strandmann (Oxford: Oxford University Press, 2000), 1-8.

Tommila, Päiviö. Suomen lehdistön levikki ennen vuotta 186o[The Circulation of the Finnish Press before 1860] (Porvoo: ws OY, 1963).

Tommila, Päiviö. "Yhdestä lehdestä sanomalehdistöksi 1809-1859" [From One Newspaper to the Press, 1809-1859]. In Suomen lehdistön historia I. Sanomalehdistön vaiheet vuoteen 1905, ed. Päiviö Tommila (Kuopio: Kustannuskiila, 1988), 77-265.

Tudeer, L. O. Th. "Piirteitä yhteisistä ylioppilaspyrinnöistä sata vuotta sitten" [Observations of student activities one hundred years ago]. Aika 8 (1914), 277-303.

Vuorinen, Heikki S. Tautinen historia [The History of Diseases] (Tampere: Vastapaino, 2002).

Werner, Michael, and Bénédicte Zimmermann. "Beyond Comparison: Histoire Croisée and the Challenge of Reflexivity." History and Theory 45 (1) (2006), 30-50.

Westermarck, Helena. Elisabeth Blomqvist. Hennes liv och gärning. En biografisk studie, enligt brev och dagboksanteckningar [Elisabeth Blomqvist. Her Life and Deed: A biographical study, according to letters and diary notes] (Helsingfors: Söderström \& Co., 1916).

Williamson, George S. "What Killed August von Kotzebue? The Temptations of Virtue and the Political Theology of German Nationalism, 1789-1819." The Journal of Modern History 72 (4) (2000), 890-943. 